\title{
KEDUDUKAN HUKUM KORBAN KEJAHATAN DALAM HUKUM PIDANA INDONESIA
}

\author{
Dwi Seno Wijanarko
}

\begin{abstract}
ABSTRAK
Peradilan Pidana Indonesia menganut asas "Perlindungan atas harkat martabat manusia". Jika dihubungkan dengan asas "Persamaan di muka hukum" sebagaimana dijelaskan dalam Pasal 31 KUHAP, maka KUHAP masih lebih condong menitikberatkan mengatur mengenai perlindungan terhadap harkat dan martabat dari tersangka dibanding dengan harkat dan martabat dari korban. Dapat dikatakan bahwa perlindungan hukum terhadap korban sangat kurang diperhatikan dalam pengaturan KUHAP dan hal ini merupakan suatu titik kelemahan yang mendasar oleh karena tidak mengatur dan memfasilitasi suatu perlindungan hukum yang bersifat komprehensif dan maksimal terhadap kepentingan korban. Dapat dikatakan bahwa perlindungan hukum terhadap korban sangat kurang diperhatikan dalam pengaturan KUHAP dan hal ini merupakan suatu titik kelemahan yang mendasar oleh karena tidak mengatur dan memfasilitasi suatu perlindungan hukum yang bersifat komprehensif dan maksimal terhadap kepentingan korban.
\end{abstract}

\section{PENDAHULUAN}

Dalam Kamus Besar Bahasa Indonesia, ${ }^{1}$ Korban adalah orang, binatang, dan sebagainya yang menjadi menderita (mati dan sebagainya), akibat suatu kejadian, perbuatan jahat dan sebagainya.

Sementara itu menurut Black's Law Dictionary: ${ }^{2}$

Victim is a person harmed by a crime, tort or other wrong.

(Korban adalah orang yang dirugikan oleh suatu kejahatan, perbuatan melawan hukum atau kesalahan lainnya)

Kamus Besar Bahasa Indonesia, Pusat Bahasa, Departemen Pendidikan Nasional, Edisi Keempat, PT Gramedia Pustaka Utama, Jakarta, 2008, hlm. 733

2 Bryan A Garner, (Editor in Chief), Black's Law Dictionary, Eight Edition, Thomson, West, St. Paul, MN, USA, 2007, hlm. 1598. 
Pada Kongres Perserikatan Bangsa-Bangsa (PBB) ke-7 (tujuh) tentang Pencegahan Kejahatan dan Perlakuan Terhadap Pelaku Kejahatan (The Seventh United Nations Conggress on the Prevention of Crime and the Treatment of Offenders) yang diadakan pada bulan September 1985 di Milan Italia, United Nations Declaration of Basic Principles of Justice for Victims of Crime and Abuse of Power dalam Pasal 1 disebutkan tentang Korban Kejahatan, yaitu:

Victim means persons who, individually or collectively, have suffered harm, including physical or mental injury, emotional suffering, economic loss or substantial impairment of their fundamental rights, through acts or omissions that are in violation of criminal law operative within member states, including those laws proscribing criminal abuse of power.

(Korban adalah orang yang secara individu atau secara bersama-sama telah mengalami penderitaan, termasuk penderitaan yang bersifat fisik atau mental, penderitaan emosional, kerugian ekonomi atau kerusakan substansial dari hak-hak dasar mereka, yang diakibatkan oleh perbuatan atau sikap tidak berbuat (omisi) yang melanggar hukum pidana yang berlaku dalam negara-negara peserta, termasuk hukum yang melarang tindakan penyalahgunaan kekuasaan.)

Di Indonesia, pembahasan mengenai korban sangat sedikit. Muladi berpendapat bahwa korban kejahatan perlu dilindungi karena: ${ }^{3}$

Pertama, masyarakat dianggap sebagai suatu wujud sistem kepercayaan yang melembaga (system of institutionalized trust). Kepercayaan ini terpadu melalui norma-norma yang diekspresikan di dalam struktur kelembagaan, seperti kepolisian, kejaksaan, pengadilan dan sebagainya. Terjadinya kejahatan atas diri korban dan bermakna penghancuran sistem kepercayaan tersebut, sehingga

Muladi, Kapita Selekta Sistem Peradilan Pidana, Badan Penerbit Universitas Diponegoro, Semarang, 1995. Lihat pula: Ridwan Mansyur, Mediasi Penal Terhadap perkara KDRT (Kekerasan Dalam Rumah Tangga), Yayasan Gema Yustisia Indonesia, Jakarta, 2010, hlm. 111-112. 
pengaturan hukum pidana dan hukum lain yang menyangkut korban akan berfungsi sebagai sarana pengembalian sistem kepercayaan tersebut.

Kedua, adanya argumen Kontrak Sosial dan Solidaritas Sosial karena Negara boleh dikatakan memonopoli seluruh reaksi sosial terhadap kejahatan dan melarang tindakan-tindakan yang bersifat pribadi. Oleh karena itu, jika terdapat korban kejahatan, maka Negara harus memperhatikan kebutuhan korban dengan cara peningkatan pelayanan maupun pengaturan hak.

Ketiga, perlindungan korban yang biasanya dikaitkan dengan salah satu tujuan pemidanaan, yaitu penyelesaian konflik. Dengan penyelesaian konflik yang ditimbulkan oleh adanya tindak pidana akan memulihkan keseimbangan dan mendatangkan rasa damai dalam masyarakat.

Menurut Angkasa, Agus Raharjo, Setya Wahyudi, Rili Windiasih, ${ }^{4}$ kedudukan korban dalam KUHP (Kitab Undang-undang Hukum Pidana) tampaknya belum optimal dibandingkan pelaku. Hal ini didasarkan atas pendapat dari Barda Nawawi Arief ${ }^{5}$ yang menyatakan bahwa bahwa dalam hukum pidana positif yang berlaku saat ini, perlindungan korban lebih banyak merupakan perlindungan abstrak atau perlindungan tidak langsung. Hal ini dapat dijelaskan sebagai berikut:

\footnotetext{
4 Angkasa, Agus Raharjo, Setya Wahyudi, Rili Windiasih, “Kedudukan Korban Tindak Pidana Dalam Sistem Peradilan Pidana (Kajian Tentang Model Perlindungan Hukum Bagi Korban Serta Pengembangan Model Pemidanaan Dengan Mempertimbangkan Peranan Korban), Jurnal Penelitian Hukum "Supremasi Hukum" Vol. 12 No. 2 Agustus 2007, FH UNIB Bengkulu, hlm. 119128, sumber: <http://www.unsoed.ac.id/newcmsfak/UserFiles/File/HUKUM/posisi_korban_SPP.htm>

5 Barda Nawawi Arief, Beberapa Aspek Kebijakan Penegakan dan Pengembangan Hukum Pidana, Citra Aditya Bakti, Bandung, 1998, hlm. 55
} 
1) KUHP belum secara tegas merumuskan ketentuan yang secara konkrit memberikan perlindungan langsung terhadap korban, misalnya dalam hal penjatuhan pidana wajib dipertimbangkan pengaruh tindak pidana terhadap korban atau keluarga korban. KUHP juga tidak merumuskan jenis pidana restitusi (ganti rugi) yang sebenarnya sangat bermanfaat bagi korban atau keluarganya. Rumusan pasal-pasal dalam KUHP cenderung berkutat pada rumusan tentang tindak pidana, pertanggungjawaban dan ancaman pidana.

2) KUHP menganut aliran neoklasik ${ }^{6}$ yang antara lain menerima berlakunya keadaan-keadaan yang meringankan bagi pelaku tindak pidana yang menyangkut fisik, lingkungan serta mental yang terefleksikan dalam Pasal 44 KUHP yang memungkinkan seorang pelaku tindak pidana tidak dijatuhi pidana. Dari hal seperti itu, tepat untuk menggambarkan bahwa korban memang sebagai pihak yang dilupakan dalam Sistem Peradilan Pidana (SPP).

Andi Hamzah menyatakan bahwa dalam membahas hukum acara pidana khususnya yang berkaitan dengan hak-hak asasi manusia, ada kecenderungan untuk mengupas hal-hal yang berkaitan dengan hak-hak tersangka tanpa memperhatikan pula hak-hak para korban. ${ }^{7}$

UU No. 8 Tahun 1981 tentang Kitab Undang-undang Hukum Acara Pidana (KUHP) dalam konsiderannya memberikan perlindungan terhadap harkat dan martabat manusia. Akan tetapi dalam penjabaran pasal-pasal di dalam dictum

\footnotetext{
Lihat Soedarto, Hukum dan Hukum Pidana, Alumni, Bandung, 1983, hlm. 55.

Andi Hamzah, Perlindungan Hak-hak Asasi Manusia dalam Kitab Undang-Undang Hukum Acara Pidana, Binacipta, Bandung, 1986, hlm. 33 dalam: Dikdik M. Arief Mansur \& Elisatris Gultom, Urgensi Perlindungan Korban Kejahatan, Antara Norma dan Realita, Rajawali Pers, Jakarta, hlm. 25
} 
serta dalam penjelasannya tidak terakomodir ketentuan yang memuat hak dan kewajiban bagi korban secara adil. Berikut ini beberapa ketentuan dalam KUHAP, yaitu: ${ }^{8}$

1) Dalam Bab I tentang Ketentuan Umum Pasal 1 yang terdiri atas angka 1 (satu) hingga 32 dan berisi tentang berbagai macam pengertian berkaitan dengan proses peradilan dengan segala aspeknya, tidak satupun yang merumuskan pengertian tentang korban.

2) Dalam Bab VI tentang Tersangka dan Terdakwa, yang terdiri atas 19 pasal, sarat dengan aturan yang memberikan hak sebagai perlindungan hak asasi manusia terhadap pelaku.

3) Bab VII tentang Bantuan Hukum dalam ketentuan pasal-pasalnya mengatur adanya beberapa hak dan kewajiban dari penasehat hukum selama proses peradilan. Hak-hak ini dapat pula dikatakan sebagai pendukung bagi terlaksananya hak-hak dari pelaku.

4) Bab XII tentang Ganti Kerugian dan Rehabilitasi, menunjukkan pula adanya beberapa hak bagi pelaku sebagai wujud dari perlindungan hukum dalam proses peradilan pidana.

5) Bab XIV tentang Penyidikan juga dijumpai ketentuan-ketentuan yang lebih berorientasi terhadap hak pelaku.

6) Dalam penjelasan dictum dan pasal-pasal, tampak bahwa KUHAP lebih berorientasi pada kepentingan pelaku daripada korban dan di bagian akhir

\footnotetext{
8 Angkasa, Agus Raharjo, Setya Wahyudi, Rili Windiasih, op.cit.
} 
dari penjelasan KUHAP disebutkan beberapa asas yang maknanya lebih dominant bagi kepentingan pelaku daripada korban.

II. Rumusan Masalah

1. Bagaimana Kedudukan Korban Kejahatan Dalam Hukum Pidana Indonesia?

III. Tujuan Penelitian

1. Untuk mengetahui Kedudukan Korban Kejahatan Dalam Hukum Pidana Indonesia

\section{TINJAUAN PUSTAKA}

Penjelasan resmi KUHAP menyatakan adanya perlakuan yang sama atas diri setiap orang di muka hukum dengan tidak mengadakan pembedaan perlakuan. Penjelasan ini pada hakekatnya memperlihatkan bahwa Sistem Peradilan Pidana Indonesia menganut asas "Perlindungan atas harkat martabat manusia". Jika dihubungkan dengan asas "Persamaan di muka hukum" sebagaimana dijelaskan dalam Pasal 31 KUHAP, maka KUHAP masih lebih condong menitikberatkan mengatur mengenai perlindungan terhadap harkat dan martabat dari tersangka dibanding dengan harkat dan martabat dari korban. Dapat dikatakan bahwa perlindungan hukum terhadap korban sangat kurang diperhatikan dalam pengaturan KUHAP dan hal ini merupakan suatu titik kelemahan yang mendasar oleh karena tidak mengatur dan memfasilitasi suatu perlindungan hukum yang bersifat komprehensif dan maksimal terhadap kepentingan korban.

Menurut Mudzakkir problem yang mendasar dalam hukum pidana Indonesia adalah tidak diakuinya posisi hukum korban kejahatan dalam sistem 
peradilan pidana yang mengakibatkan korban secara sistematik dikeluarkan dari penyelenggaraan peradilan pidana. ${ }^{9}$ Dalam praktik peradilan pidana, Hakim dalam putusannya hanya mendasarkan atas apa yang didakwakan dan yang dituntut, sehingga dalam menjatuhkan putusannya hakim pada umumnya hanya memperhatikan requisitoir/tuntutan, sementara korban tidak disinggung dan kepentingan korban tidak ter"cover" dalam putusan tersebut.

\section{PEMBAHASAN}

Dalam berbagai ketentuan dalam hukum positif Indonesia ditemukan berbagai istilah hukum yang secara tidak langsung berhubungan dengan kepentingan korban kejahatan, yaitu: korban kejahatan sebagai "Saksi" diatur dalam Pasal 1 ke 27 KUHAP, “Pengadu” (Pasal 72 KUHP) "Pihak Ketiga Yang Berkepentingan" (Pasal 80 dan 81 KUHAP), "Pihak Yang Dirugikan" (Pasal 98 dan 99 KUHAP). ${ }^{10}$ "Pelapor" (Pasal 108 KUHAP) ${ }^{11}$ atau, "Saksi" atau "Saksi Korban" (Pasal 160 KUHAP).

Istilah-istilah tersebut tidak mengatur eksistensi dan posisi hukum korban kejahatan dalam sistem peradilan pidana. Adanya ketentuan-ketentuan tersebut

9 Mudzakkir, Posisi Hukum Korban Kejahatan dalam Sistem Peradilan Pidana, Disertasi, Program Pasca Sarjana Fakultas Hukum Universitas Indonesia, Jakarta, April 2001, ibid, hlm. 3

10 Istilah "pihak yang dirugikan" dalam penjelasannya juga termasuk "korban kejahatan" (Penjelasan Pasal 98 ayat 1). Istilah "korban kejahatan" sebagai pihak yang dirugikan dalam pelanggaran hukum pidana dipergunakan oleh KUHAP dalam konteks keperdataan, yakni penggabungan perkara perdata dalam prosedur acara pidana.

11 Ketentuan dalam KUHAP tersebut tidak bersanksi, sedangkan wajib lapor yang diatur Pasal 164-166 KUHP yang cakupannya diperluas, yakni keharusan melapor jika mengetahui adanya permufakatan untuk melakukan kejahatan terhadap keamanan Negara, dapat diancam dengan pidana penjara. 
belum bisa menjamin sepenuhnya akses korban untuk memperoleh keadilan dalam sistem peradilan pidana.

1. Dalam Tahapan Penyelidikan/Penyidikan

Korban hanya memberikan laporan atau pengaduan, tindakan selanjutnya diserahkan pada aparat. Laporan atau pengaduan berguna bagi kepolisian untuk melakukan tindakan penyelidikan. Dengan demikian, pada tingkat ini kedudukan dan peran korban adalah sebagai pelapor atau pembuat aduan.

\section{Dalam Tahapan Penuntutan}

Walaupun korban telah melaporkan terjadinya tindak pidana dan polisi telah menahan pelakunya, Jaksa Penumtut Umum dapat tidak melanjutkankan proses pidana yaitu melakukan penuntutan ke pengadilan. Hal ini disebabkan hal-hal sebagai berikut:

Pertama, bahwa sekalipun telah dilakukan penahanan oleh Polisi terhadap pelakunya namun berdasarkan pertimbangan Jaksa ternyata kasus tersebut bukanlah merupakan merupakan suatu tindak pidana.

Kedua, jika berdasarkan pertimbangan hukum Jaksa ternyata tidak cukup bukti. Yaitu Jaksa telah mengembalikan berkas perkara ke polisi agar alat bukti dilengkapi namun setelah polisi menyerahkan kembali berkas perkara ternyata tetap tidak cukup bukti. ${ }^{12}$

Ketiga, atas dasar asas Oportunitas dari Jaksa Agung, kasus tersebut dikesampingkan demi kepentingan umum sesuai ketentuan Pasal 35 huruf c UU No. 16 Tahun 2004 tentang Kejaksaan Republik Indonesia atau "perkara ditutup

12 Pasal 138 jo. Pasal 140 KUHAP. 
demi hukum" berdasarkan ketentuan Pasal 140 ayat (2) huruf a KUHAP. Menurut Pedoman Pelaksanaan KUHAP diberikan penjelasan bahwa "perkaranya ditutup demi hukum" diartikan sesuai dengan Buku I KUHP Bab VIII tentang Hapusnya Hak Menuntut tersebut dalam Pasal 76, 77 dan 78 KUHP (non bis in idem, terdakwa meninggal, dan lewat waktu). ${ }^{13}$

3. Dalam Proses Persidangan Perkara Pidana

Ketika korban kejahatan dipanggil ke pengadilan, ia diperlakukan sebagai saksi untuk negara. Sebagai saksi adalah suatu hak dan kewajiban hukum. Menolak menjadi saksi adalah kejahatan dan diancam dengan pidana.

Apabila keterangan yang diberikan oleh korban dianggap sudah mencukupi, maka selesai pulalah kedudukan dan peranan korban dalam mekanisme peradilan pidana.

Sementara itu dalam Hukum Pidana Formil di luar KUHP, kedudukan "sebagai korban kejahatan" termasuk kedudukan sebagai "saksi" dalam sistem peradilan pidana diakui keberadaannya, sebagaimana diatur dalam:

1. UU No. 26 Tahun 2000 tentang Pengadilan Hak Asasi Manusia.

2. UU No. 15 Tahun 2003 tentang Pemberantasan Tindak Pidana Terorisme. Korban berhak memperoleh Kompensasi dan Restitusi. ${ }^{14}$

3. UU No. 23 Tahun 2004 tentang Penghapusan Kekerasan Dalam Rumah Tangga.

\footnotetext{
13 Pedoman Pelaksanaan KUHAP, dikeluarkan oleh Departemen Kehakiman Republik Indonesia, cetakan ke-2, hlm. 68 dalam: Andi Hamzah, Hukum Acara Pidana Indonesia, Edisi Kedua, Sinar Grafika, 2008, hlm. 163

${ }^{14}$ Pasal 36 UU No. 15 Tahun 2003 tentang Terorisme.
} 
4. UU No. 13 Tahun 2006 tentang Perlindungan Saksi dan Korban jo. UU No. 31 Tahun 2014 tentang Perubahan UU No. 13 Tahun 2006 tentang Perlindungan Saksi dan Korban

5. UU No. 21 tahun 2007 tentang Pemberantasan Tindak Pidana Perdagangan Orang

6. UU No. 22 Tahun 2009 tentang Lalu Lintas dan Angkutan Jalan

Dalam hal kedudukan korban kejahatan ditempatkan sebagai "pihak ketiga yang berkepentingan”, maka dalam KUHAP, hak-hak yang lahir dalam kedudukan tersebut adalah:

a. Hak mengajukan pra-peradilan dalam hal terdapat tindakan penghentian penyidikan/penuntutan. (Pasal 80 KUHAP)

b. Hak untuk mengajukan ganti kerugian dalam konteks keperdataan berdasar Pasal 98 KUHAP.

Menurut Ketentuan Pasal 1 butir 24 KUHAP, Laporan adalah pemberitahuan yang disampaikan oleh seorang karena hak atau kewajiban berdasarkan undang-undang kepada pejabat yang berwenang tentang telah atau sedang atau diduga akan terjadinya peristiwa pidana. Kewajiban melapor menurut hukum adalah hak dari seseorang, terkecuali yang diatur dalam Pasal 164 KUHP sampai dengan Pasal 166 KUHP maka kewajiban melapor adalah merupakan kewajiban dengan ancaman sanksi pidana jika tidak melakukannya.

KUHAP tidak memberikan pengertian "Pengadu", namun dalam ketentuan Pasal 1 butir 25 KUHAP dijelaskan bahwa Pengaduan adalah pemberitahuan disertai permintaan oleh pihak yang berkepentingan kepada pejabat yang 
berwenang untuk menindak menurut hukum seorang yang telah melakukan tindak pidana aduan yang merugikannya.

Sekalipun di dalam KUHP tidak diatur hak-hak korban, namun sesungguhnya hak korban itu secara implisit terdapat dalam "delik aduan". Hak korban akan muncul dalam konteks terkait delik aduan. Korban mempunyai hak/kewenangan $100 \%$ apakah dia akan mengadu atau tidak mengadu. Dalam delik aduan korban dapat menegosiasikan kepentingannya secara penuh apakah perkaranya diajukan pidana atau tidak, dan korban berhak untuk melakukan "penyelesaian di luar pengadilan" (out of court settlement). "Penyelesaian di luar pengadilan" dalam suatu konteks dimana sebelum di proses ke pengadilan, korban dapat melakukan negosiasi untuk menuntut haknya akibat adanya kerugian yang dia diderita dengan akibat perbuatan melawan hukum. Jika korban tidak bersedia untuk penyelesaian di luar pengadilan, maka kasus itu berlanjut dibawa ke pengadilan. Dalam hal kasus itu dibawa ke pengadilan, maka haknya hilang. Jika dibawa ke pengadilan dan dilakukan penuntutan maka berubah menjadi "delik biasa”, hal ini berarti korban kejahatan tidak lagi mempunyai hak hukum.

Kedudukan korban di dalam tahapan penyelidikan dan penuntutan dan proses sidang pengadilan pemeriksaan perkara pidana adalah dapat sebagai "saksi". Korban sebagai saksi (Saksi Korban) disebutkan sebagai yang pertamatama didengar keterangannya sebagai saksi dalam pemeriksaan sidang pengadilan. ${ }^{15}$ Keterangan Saksi yang disumpah yang dinyatakan di sidang pengadilan adalah alat bukti yang sah. [Pasal 185 ayat (1))

15 Pasal 160 ayat (2) KUHAP. 
a. Kewajiban Korban sebagai saksi:

1). Memenuhi panggilan pengadilan untuk memberikan kesaksian, dengan ancaman pidana apabila tidak mematuhinya sesuai Pasal 224 KUHP.

2). Memberikan keterangan dengan sebenarnya berdasarkan Pasal 242 KUHAP, dengan ancaman pelanggaran pidana melanggar Pasal 242 KUHP karena "sumpah palsu".

b. Hak dari saksi:

Dalam hal saksi merasa tertekan atau tidak bebas dalam memberikan keterangan apabila terdakwa hadir di sidang. Pasal 173 KUHAP mengatur bahwa dalam hal menurut pendapat hakim seorang saksi itu akan merasa tertekan atau tidak bebas dalam memberikan keterangan apabila terdakwa hadir di sidang, maka untuk menjaga hal yang tidak diinginkan hakim dapat menyuruh terdakwa ke luar untuk sementara dari persidangan selama hakim mengajukan pertanyaan kepada saksi. Hak dari saksi korban adalah sebagai berikut:

- Memperoleh penterjemah jika ia tidak mengerti Bahasa Indonesia (Pasal 177 KUHAP);

○ Hak untuk mengundurkan diri sebagai saksi karena termasuk yang menurut hukum tidak dapat didengar keterangannya, misalnya: keluarga sedarah atau semanda dalam garis lurus ke atas atau ke bawah sampai derajat ketiga dari terdakwa atau yang bersama-sama sebagai terdakwa (Pasal 168 KUHAP).

Dalam peraturan perundang-undangan tertentu di luar KUHP, hak-hak korban tersebut adalah:

1. Hak untuk menuntut Ganti Kerugian. 
2. Hak untuk memperoleh Kompensasi dalam bentuk uang atau harta benda.

3. Hak untuk memperoleh perlindungan. "Perlindungan" dalam konteks ini adalah "rasa aman". Instansi penegakan hukum di sini adalah Lembaga Perlindungan Saksi dan Korban (LPSK).

4. Hak lain dalam kapasitasnya menjadi "saksi". Terkait di sini adalah LPSK dan Kepolisian.

\section{PENUTUP}

Berdasarkan pembahasan yang telah diuraikan, maka dapat ditarik kesimpulan sebagai berikut :

a. Kedudukan hukum korban kejahatan dalam KUHAP sebagai Hukum Pidana Formil tidak diakui keberadaannya (tidak ada). Demikian pula dalam KUHP (Hukum Pidana Materiel).

b. Kedudukan hukum "korban kejahatan" telah diakui keberadaannya dalam Hukum Pidana Materiel di luar KUHP (UU No. 26 Tahun 2000 tentang Pengadilan Hak Asasi Manusia, UU No. 15 Tahun 2003 tentang Pemberantasan Tindak Pidana Terorisme, UU No. 23 Tahun 2004 tentang Penghapusan Kekerasan Dalam Rumah Tangga, UU No. 13 Tahun 2006 tentang Perlindungan Saksi dan Korban jo. UU No. 31 Tahun 2014 tentang Perubahan UU No. 13 Tahun 2006 tentang Perlindungan Saksi dan Korban, UU No. 21 tahun 2007 tentang Pemberantasan Tindak Pidana Perdagangan Orang, UU No. 22 Tahun 2009 tentang Lalu Lintas dan Angkutan Jalan. 


\section{DAFTAR PUSTAKA}

Andi Hamzah, Hukum Acara Pidana Indonesia, Edisi Kedua, Sinar Grafika, 2008

Perlindungan Hak-hak Asasi Manusia dalam Kitab UndangUndang Hukum Acara Pidana, Binacipta, Bandung, 1986

Angkasa, Agus Raharjo, Setya Wahyudi, Rili Windiasih, "Kedudukan Korban Tindak Pidana Dalam Sistem Peradilan Pidana (Kajian Tentang Model Perlindungan Hukum Bagi Korban Serta Pengembangan Model Pemidanaan Dengan Mempertimbangkan Peranan Korban), Jurnal Penelitian Hukum "Supremasi Hukum" Vol. 12 No. 2 Agustus 2007, FH UNIB Bengkulu

Barda Nawawi Arief, Beberapa Aspek Kebijakan Penegakan dan Pengembangan Hukum Pidana, Citra Aditya Bakti, Bandung, 1998

Bryan A Garner, (Editor in Chief), Black's Law Dictionary, Eight Edition, Thomson, West, St. Paul, MN, USA, 2007

Dikdik M. Arief Mansur \& Elisatris Gultom, Urgensi Perlindungan Korban Kejahatan, Antara Norma dan Realita, Rajawali Pers, Jakarta

Imron Anwari, Kedudukan Hukum Korban Kejahatan Dalam Sistem Peradilan Pidana Indonesia, Melalui Putusan-Putusan Pengadilan Pidana, Disertasi, UNPAD Bandung, 2012

Kamus Besar Bahasa Indonesia, Pusat Bahasa, Departemen Pendidikan Nasional, Edisi Keempat, PT Gramedia Pustaka Utama, Jakarta, 2008

Mudzakkir, Posisi Hukum Korban Kejahatan dalam Sistem Peradilan Pidana, Disertasi, Program Pasca Sarjana Fakultas Hukum Universitas Indonesia, Jakarta, April 2001

Muladi, Kapita Selekta Sistem Peradilan Pidana, Badan Penerbit Universitas Diponegoro, Semarang, 1995.

Ridwan Mansyur, Mediasi Penal Terhadap perkara KDRT (Kekerasan Dalam Rumah Tangga), Yayasan Gema Yustisia Indonesia, Jakarta, 2010

Soedarto, Hukum dan Hukum Pidana, Alumni, Bandung, 1983

Rujukan Elektronik:

http://www.unsoed.ac.id/newcmsfak/UserFiles/File/HUKUM/posisi_korban_SPP. htm 